\title{
Evaluation of different insecticides against green semilooper, Thysanoplusia orichalcea (Fab.) in soybean ecosystem
}

\author{
M.V. MATTI* AND R.O. DEOTALE \\ Entomology Section, College of Agriculture, NAGPUR (M.S.) INDIA
}

\section{ARITCLE INFO}

Received : 03.08 .2015

Revised : 28.08 .2015

Accepted : 13.09 .2015

\section{KEY WORDS :}

Semilooper, Soybean, Spinosad, Emamectin benzoate, Fenvalrate, Yield

*Corresponding author:

Email: muttumatti@gmail.com

\begin{abstract}
A field study was conducted during Kharif season 2014-15 to determine the efficacy of different insecticides against semilooper Thysanoplusia orichalcea (Fab.) in soybean ecosystem in the insectory premises of Agricultural Entomology Section, College of Agriculture Nagpur. Least cumulative average number larvae $(0.05 / \mathrm{mrl})$ was recorded in treatment of Fenvalerate $20 \mathrm{EC} @ 0.50 \mathrm{ml} / \mathrm{l}\left(\mathrm{T}_{7}\right)$ found to be superior compared to other treatments. The next effective treatments were emamectin benzoate $5 \mathrm{SG} @ 0.3 \mathrm{~g} /$ $1\left(\mathrm{~T}_{6}: 0.06 / \mathrm{mrl}\right)$ and also in Spinosad $45 \mathrm{SC} @ 0.25 \mathrm{ml} / 1$ ( $\left.\mathrm{T}_{3}: 0.07 / \mathrm{mrl}\right)$, Indoxacarb $15.8 \mathrm{EC}$ @ $0.60 \mathrm{ml} / 1\left(\mathrm{~T}_{5}: 0.08 / \mathrm{mrl}\right)$ found to be at par with $\mathrm{T}_{6}$ and $\mathrm{T}_{3}$. However, the treatment Neem Oil 2 per cent $\left(\mathrm{T}_{2}\right)$ recorded 0.78 larvae/mrl. Whereas, NSE @ 5 per cent $\left(\mathrm{T}_{1}: 0.95 / \mathrm{mrl}\right)$ and Beauveria bassiana $1 \times 10^{8} \mathrm{CFU} @ 4 \mathrm{~g} / 1\left(\mathrm{~T}_{4}: 0.99 / \mathrm{mrl}\right)$ were found to be least effective in reducing larval population/mrl. Maximum mean larval population $(1.48 / \mathrm{mrl})$ was recorded in control (Water spray; $\mathrm{T}_{8}$ ). Fenvalerate $20 \mathrm{EC} @ 0.50 \mathrm{ml} / \mathrm{l}$, Indoxacarb 15.8 EC @ $0.60 \mathrm{ml} / 1$, Spinosad $45 \mathrm{SC} @ 0.25 \mathrm{ml} / 1$ were found to be most effective treatments which recorded highest yield of $21.05 \mathrm{q} / \mathrm{ha}, 20.10 \mathrm{q} / \mathrm{ha}$ and $19.02 \mathrm{q} / \mathrm{ha}$, respectively. From the seed production point of view Fenvalerate 20 EC @ $0.50 \mathrm{ml} / \mathrm{l}$, Indoxacarb 15.8 EC @ $0.60 \mathrm{ml} / 1$, Spinosad 45 SC @ $0.25 \mathrm{ml} / 1$ were most effective in recording highest yield.
\end{abstract}

How to view point the article : Matti, M.V. and Deotale, R.O. (2015). Evaluation of different insecticides against green semilooper, Thysanoplusia orichalcea (Fab.) in soybean ecosystem. Internat. J. Plant Protec., 8(2) : 338-342. 